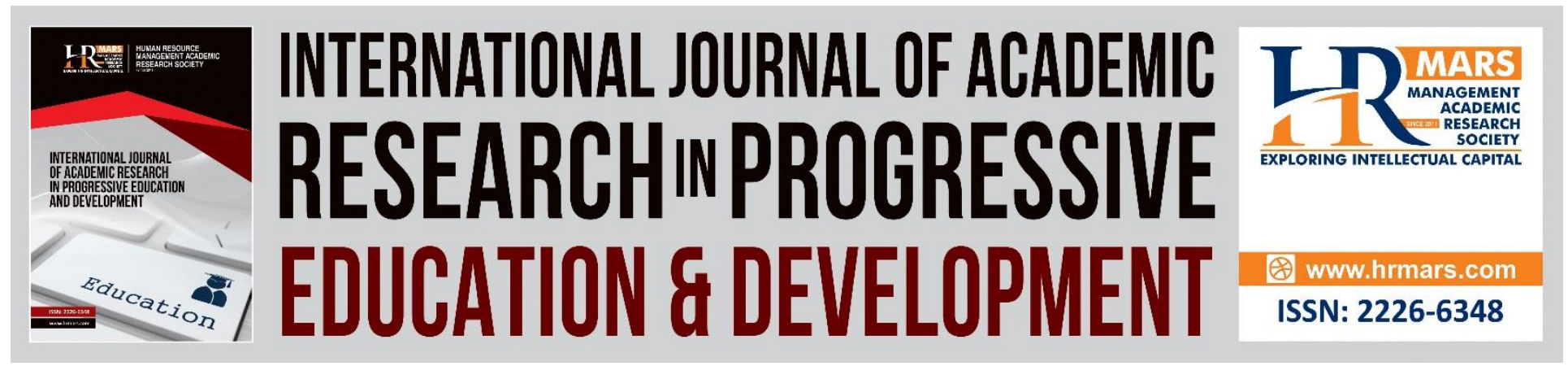

\title{
A Mediation Analysis of the Effect of Principal's Transformational Leadership on the Relationship between Total Quality Management and Teacher Quality
}

\author{
Mohd Rahimi A Rahman, Mohamed Yusoff Mohd Nor, Jamalul Lail Abdul \\ Wahab \& Ashairi Suliman
}

To Link this Article: http://dx.doi.org/10.6007/IJARPED/v9-i2/7970

DOI:10.6007/IJARPED/v9-i2/7970

Received: 10 May 2020, Revised: 29 May 2020, Accepted: 16 June 2020

Published Online: 26 July 2020

In-Text Citation: (Rahman, Nor, Abdul Wahab, \& Suliman, 2020)

To Cite this Article: Rahman, M. R. A., Nor, M. Y. M., Abdul Wahab, J. L., \& Suliman, A. (2020). A Mediation Analysis of the Effect of Principal's Transformational Leadership on the Relationship between Total Quality Management and Teacher Quality. International Journal of Academic Research in Progressive Education \& Development. 9(2), 786-804.

Copyright: (c) 2020 The Author(s)

Published by Human Resource Management Academic Research Society (www.hrmars.com)

This article is published under the Creative Commons Attribution (CC BY 4.0) license. Anyone may reproduce, distribute, translate and create derivative works of this article (for both commercial and non-commercial purposes), subject to full attribution to the original publication and authors. The full terms of this license may be seen at: http://creativecommons.org/licences/by/4.0/legalcode

Vol. 9(2) 2020, Pg. 786 - 804

http://hrmars.com/index.php/pages/detail/IJARPED JOURNAL HOMEPAGE

Full Terms \& Conditions of access and use can be found at http://hrmars.com/index.php/pages/detail/publication-ethics 


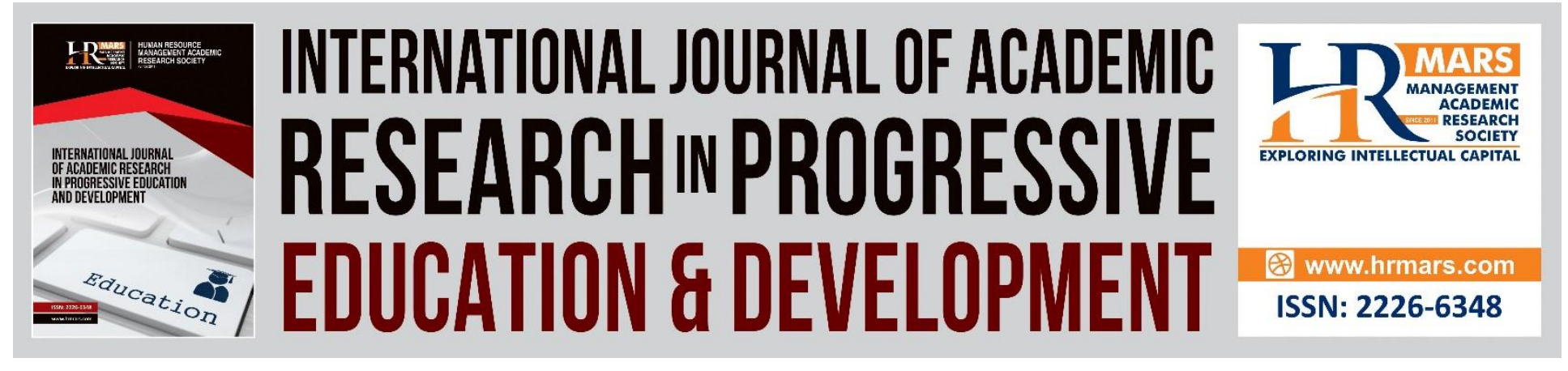

\title{
A Mediation Analysis of the Effect of Principal's Transformational Leadership on the Relationship between Total Quality Management and Teacher Quality
}

\author{
Mohd Rahimi A Rahman, Mohamed Yusoff Mohd Nor, Jamalul \\ Lail Abdul Wahab \& Ashairi Suliman \\ Faculty of Education, National University of Malaysia, 43600 Bangi, Selangor, Malaysia \\ Email: p87889@siswa.ukm.edu.my
}

\begin{abstract}
This study aims to examine the relationship between total quality management practice and teacher quality in secondary schools, as well as to identify the effect of principal's transformational leadership style on the relationship between both. This study used a crosssectional survey involving 423 secondary school teachers from all over Malaysia. This study utilised the Pearson's correlation inference analysis to determine the relationship between variables and SPSS Macro Process 3.0 analysis to identify the mediating effect. The results showed that the relationship between total quality management practice and principal's transformational leadership style is positive and significant, where reward demonstrated the most significant relationship. Furthermore, the relationship between the principal's transformational leadership style and teacher quality also indicates a positive relationship in which inspirational motivation also shows the highest value of relationships. In addition, total quality management has a positive and significant relationship with teacher quality with continuous improvement shows the highest value of relationships. Additionally, the Value Adjustment Factor (VAF) for mediating effect was $24.4 \%$. Thus, this study has demonstrated that total quality management practice has a partial mediating effect on teacher quality.

Keywords: Total Quality Management, Principal's Transformational Leadership Style, Teacher Quality, Secondary School, Mediating Effect.

\section{Introduction}

Teachers play a significant role in achieving school effectiveness and student achievement, specifically through the implementation of an effective education system to create a highly educated, knowledge-driven society (MOE, 2016). Teachers are essential components in the organization, specifically in realising the country's educational aspiration (Talib, Mansor \& Surat,
\end{abstract}


2019). The field of education is evolving in line with the development of state-of-the-art technology. In this regard, the National Philosophy of Education has been established as part of the government's effort to produce holistic individuals with balanced spiritual, physical and emotional growth with the potential to achieve personal well-being and contribute to the country's harmony and prosperity (Nordin \& Othman, 2008). Based on the above argument, quality teachers are very important to the quality of an education system. In other words, teachers' quality is an essential factor in achieving teacher's self-efficacy in educating students in schools (Nilsen, Trude \& Gustaffsson, 2016). Teachers' quality can also reflect a teacher's job satisfaction (Yahya, Azizah \& Yaakob, 2014). This is because high-quality teachers reflect their commitment to carry out the responsibilities, gain new knowledge and skills, job loyalty and their willingness to perform their task willingly without any coercion (MOE, 2016).

In this light, the aspect of teacher quality needs to be taken into account, given the increasing teachers' workload. This is because quality teachers who are creative, efficient, highly motivated and well-educated, are one of the key elements in enhancing the effectiveness of teaching and learning in schools (Mau, Ellsworth \& Hawley, 2004). All these aspects can be fulfilled if the teachers have a high level of work and personal qualities. Therefore, quality teachers play an important role in fulfilling the goals of the education system and in achieving their school's goals (Shahril, 2005).

Having high-quality teachers is an important aspect to fulfil Malaysia's aspiration to become a developed and educated country. It is argued that quality teachers will demonstrate the best work performance. This could increase the productivity, capacity and excellence in a school (Ishak \& Rusman, 2018). Hence, it is important to create a successful future generation future. On the other hand, the level of teacher's quality might differ across individuals. This situation creates a challenge in measuring and quantifying teacher's quality as teachers have different responsibilities, burdens, problems, exposure and experiences (Mau, Ellsworth \& Hawley, 2004).

In 2007, a comprehensive study conducted by the committee on Teachers' workload and Responsibility found that a teacher in Malaysia spends an average of 66.24 hours a week to perform her duties and responsibilities as an educator (MOE, 2007). This amount is greater than the average weekly work hours recommended by the International Labour Organisation (ILO), which is 45 hours a week. This research states that Malaysian teachers are often burdened with not only tasks related to the curriculum and co-curricular activities, but also tasks related to community relations, staff development, physical development, administrative works, finance, student affairs and hostel management. It was reported teachers are required to do additional administrative tasks on top of curriculum- elated tasks such as teaching, lesson planning, lesson preparation, assessment, and additional classes (MOE, 2007). The issue of teachers' workload has led to the implementation of quality management initiatives in the Malaysian public services. These initiatives include Total Quality Management (TQM), Innovative and Creative (KIK) practices, Work Quality Improvement Group (KMK) and Quality School Management System (SPSK). In this light, while these quality management practices should be implemented in the public service to ensure effective government service delivery, the implementation of quality management is still poorly implemented at the school level (Rahim, Rahman \& Daud, 2012). 
Leadership is a process of influencing a group of individuals towards a common goal or vision performance (Alnawasreh, Nor \& Suliman, 2019). On top of that, transformational leadership is an important aspect of shaping the culture and effectiveness of a school, and it was found that effective transformational leadership could positively influence job satisfaction and teacher commitment (Wahab, Faud, Ismail \& Majid, 2014). Each principal adopts his/her style of leadership, depending on their school's circumstances. Studies have reported that most principals practice transformational leadership to influence teacher's attitudes and behaviours so that they can work towards achieving the school's goals. Existing transformational leadership needs to be continually improved to ensure the school's sustainability as a learning institution (Hamzah, Mat, Nordin \& Rahman, 2011). It is stipulated that a leader should practice transformational leadership according to his employees' conditions and attitudes (Bass \& Bass, 2008). Hence, this study will identify the needs for implementing transformational leadership among school leaders to ensure teachers can accept and implement effective total quality management in schools.

Good school quality management practices will make schools effective without relying solely on the principal's leadership effectiveness (Davies \& Burnham, 2010). These practices will allow a school to maintain its quality despite the change of hands in leadership. The quality of teachers and all aspects in the school can be systematically shaped to produce students who are excellent in every aspect (Davies \& Burnham, 2010). Effective quality management practices will also ensure that the teachers and the school staff are able to take on their tasks and responsibilities according to the guidelines provided by the school's quality management. As a result, teachers will produce quality work and at the same time, able to fulfil the students' learning needs.

Based on the issues, problems, and challenges discussed earlier, there is still room for studying the gaps in teacher quality. This could be done by adopting a more comprehensive and effective approach which incorporates total quality management practices. The purpose of this study is to identify the relationship between the implementation of total quality management practices, transformational leadership and teacher quality. In addition, this study also examines the role of transformational leadership as the mediator variable on the relationship between quality management practices and teacher quality in secondary schools.

This study provides an overview of the relationship between the independent variable (total quality management), the moderating variable (transformational leadership) and the dependent variable (teacher quality). The framework of this study is based on the extended Model of Social Cognitive Career Theory developed by (Lent \& Brown, 2006). The model presents a more detailed model of individual achievement AND was developed to understand teachers' career factors in education and vocational education (Lent \& Brown, 2006). The extended model also emphasises on the relationship between behaviour, environmental factor, and an individual's development and achievement (Lent \& Brown, 2006). The main framework of this study is supported by three main models, which are Total Quality Management Model (Oakland, 2014), Transformational Leadership Theory (Bass, 1985) and the Malaysian Teacher Standards (MOE, 2008). 


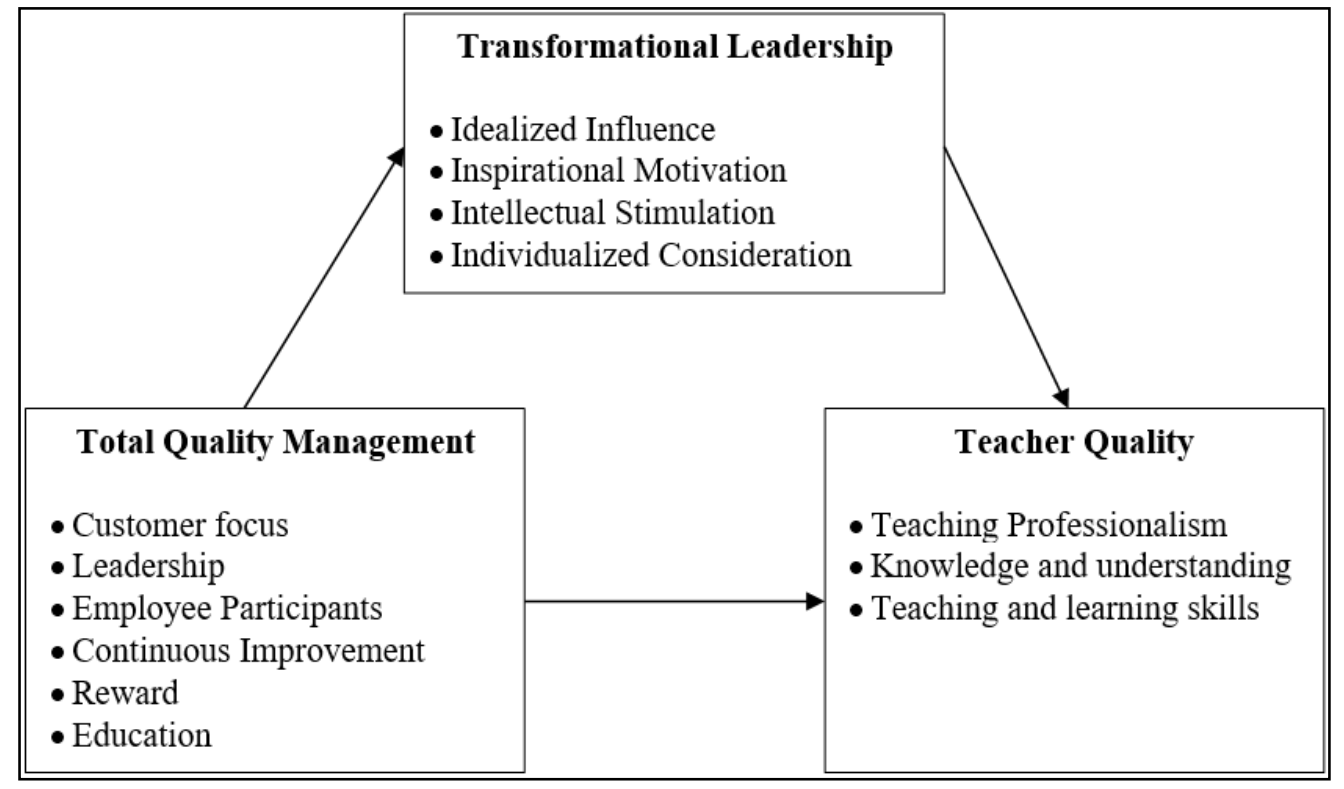

Figure 1. Relationship between Total Quality Management and Teacher Quality: Principal's Transformational Leadership as Mediator

\section{Literature Review \\ Total Quality Management}

the quality management practices in this study refer to the set of beliefs, norms, rules and values which are accepted as true and can be used as the basis for quality management practices (Davies \& Burham, 2010). total quality management also ensures an organisation's ability to use its resources optimally to meet the needs and wants of the customers and stakeholders of the organization (Oakland, 2014). total quality management practices in this study include customer focus, leadership, employee participant, continuous improvement, rewards and education.

\section{Transformational Leadership}

Transformational leadership refers to a leader's encouraging and prompting leadership in attaining accredited employees who are highly capable of producing extraordinary outcomes and synchronising an organisations objectives and goals. Transformational leadership would result in an employee's self-satisfaction and constant commitment towards the organisation and the assigned group of employees (Bass, 1985). Bass \& Bass (2008) further proposed that a transformational leader is a leader who can optimize his employees' abilities in line with Maslow's hierarchy of needs, as well as for the employees' self-fulfilment. In this study, transformational leadership shall be discussed within the context of a school's principal, where the individual underpinning characteristics are inclusive of idealised influence, inspirational motivation, intellectual stimulation and individualized consideration.

\section{Teacher Quality}

Teacher quality is described as the self-quality and the duties of a teacher (Yahya, Azizah \& Yaakob, 2014). Teacher quality in this study refers to teachers' self-esteem and work quality. 
These aspects will be measured based on the teaches' professionalism practice, knowledge and understanding, as well as teaching and learning skills in improving students' achievement and performance.

\section{Problem Statement}

Past studies on total quality management involve the influence of quality management on product (Jayaram, Ahire, Nicolae \& Ataseven, 2011; RK Singh, 2011), organizational culture (Lam, Poon \& Chin, 2008; Leithwood, Jantzi, Dimmock, Goh, Mulford, Kendall \& Ewington, 2012; Sihotang \& Zebedeus, 2013), job satisfaction (Morrow, Mcelroy \& Scheibe, 2011; Oluwatoyin \& Oluseun, 2014; Ooi, Bakar, Arumugam, Vellapan \& Loke, 2007; Ugboro \& Screwdriver, 2000), customer satisfaction (Abu-Doleh, 2012; Chang, Chiu \& Chen, 2010; Morrow, Mcelroy \& Scheibe, 2011; Psomas \& Fotopoulos, 2010; Sakthivel, Rajendran \& Raju, 2005; Singh, 2011; Ugboro \& Obeng, 2000), achievements (Alolayyan, Ali \& Idris, 2011) and leadership (Alolayyan, Ali \& Idris, 2011; Chang, Chiu \& Cheng, 2010; Lam, Poon \& Chin, 2008; Nawelwa, Sichinsambwe \& Mwanza, 2015; Oluwatoyin \& Oluseun, 2014; Sallis, 2008; Ugboro \& Obeng, 2000). However, studies concerning the relationship between total quality management and teacher quality, especially in secondary schools are still lacking (Koch, 2003; Nawelwa, Sichinsambwe \& Mwanza, 2015; Svensson \& Klefsjo, 2006; Yahya, Azizah \& Yaakob, 2014). In fact, this is a new sheet in the study related to principals' transformational leadership as a mediating factor in the relationship between total quality management and teacher quality.

Teacher quality is an important element in determining the success of a school and the outcome of a student. The teacher quality concept has been highlighted since 1970 s and is relevant even now (Blanton, Sindelar \& Correa, 2006). It is an important factor that determines the development of students. A preliminary study by Sanders \& Rivers (1996) proved that two students of similar age with moderate performance can show different achievement over a period of three years when taught by two teachers with different performance. Quality teachers play an important role besides students' educational background, demographic, socio-economic status and others (Arifin, Mustapa, My, Arab, Islam, Islam, Ahmad, 2014; Goe, 2007). Although there are many studies disclosed that teacher quality affects students' achievement, but less research has zoomed into the Malaysian context. Therefore, this study is important to improve the quality of teachers and further students' achievement.

Good school management practice will form an effective school without expecting the principals' leadership capabilities (Davies \& Burnham 2010). Although principals keep changing, quality management practice would maintain the quality of schools and teachers because they can be systematically formed resulting in the production of successful students (Davies \& Burnham 2010). Effective quality management practice will ensure teachers and school staff to carry out daily tasks and responsibilities according to the guidelines provided (Eksan \& Bakar, 2017) and further produce quality work while improve students' achievement (Goe, 2007).

Principal management patterns have now been developed with a variety of leadership styles. There are various types of leadership such as instructional leadership, distributed leadership, transaction leadership and capability leadership. Each principal adopts his own leadership style depending on the situation. A leader can also integrate leadership styles based on the circumstances in the organization (Bass \& Bass, 2008). However, transformational leadership is 
perceived as a leadership style that can change the attitudes and behaviours of teachers (Burns, 1978). Thus, this study examines the level of transformational leadership practised by principals besides the relationship of transformational leadership and teacher quality. In fact, this study will also look into the dimensions of transformational leadership that mostly influence teacher quality. As principals need to implement transformational leadership to influence teachers' attitudes and behaviours, it is made as the mediator to see the impact of transformational leadership in the relationship between quality management practice and teacher quality.

Based on the issues, problems and challenges discussed, this study was conducted to answer the questions of this study. Thus, they may fill the gap discussed earlier. This study is not only helping researchers to understand the implementation of total quality management and its relationship with teacher quality as well as the impact of principals' transformational leadership in these relationships. In fact, this study can also help other researchers by discussing other aspects and methods.

\section{Materials and Methods Study Design}

This study used the cross-sectional survey method to obtain data. The data were collected only at one point in time. This study's respondents consist of secondary school teachers from across Malaysia. This study involved numerical data which were then analysed by statistical tests. This study conducted a descriptive form of correlation which examines the relationship between total quality management and teacher quality. This study describes the phenomenon by analysing the data obtained from the instrument, which is in the form of a questionnaire. The data obtained were classified according to the specified aspect and quantitatively interpreted. The data analysis also involved the reliability and validity of the instrument, constructing facts and identifying the relationships between variables.

\section{Sample}

This study's population consists of teachers teaching in national secondary schools. In general, these teachers have different responsibilities and responsibilities than teachers teaching in other types of schools. In this regard, the characteristics of students in the national secondary schools will influence the quality of teachers as these students are relatively heterogeneous and come from different and socio-cultural backgrounds. This study involved 423 teachers. The number of samples was determined based on the appropriate sample size as noted in the literature, as well as the study's design, procedure and statistical analyses.

This study used simple random sampling procedure and proportional random sampling. The simple random sampling was used to ensure that each person in the population has the same opportunity to be selected as the study's respondent. The simple random sampling was also used to select the states and teachers involved in this study. Whereas, random sampling was used to calculate the number of schools involved in this study based on the actual number of schools in the selected state and based on the number of samples required. 
INTERNATIONAL JOURNAL OF ACADEMIC RESEARCH IN PROGRESSIVE EDUCATION AND

DEVELOPMENT

Vol. 9, No. 2, 2020, E-ISSN: $2226-6348$ @ 2020 HRMARS

Table 1. Teachers' demographic profile

\begin{tabular}{|c|c|c|c|}
\hline Profile & Category & Frequency & Percentage (\%) \\
\hline \multirow{3}{*}{ Gender } & Male & 118 & 27.9 \\
\cline { 2 - 4 } & Female & 305 & 72.1 \\
\cline { 2 - 4 } & Total & 423 & 100 \\
\hline \multirow{3}{*}{ Level of Education } & Graduate & 322 & 76.1 \\
\cline { 2 - 4 } & Post- & 101 & 23.9 \\
\cline { 2 - 4 } & Graduate & & 100 \\
\cline { 2 - 4 } & Total & 423 & 75.2 \\
\hline \multirow{2}{*}{ Locality of School } & Urban & 318 & 24.8 \\
\cline { 2 - 4 } & Rural & 105 & 100 \\
\cline { 2 - 4 } & Total & 423 & \\
\hline
\end{tabular}

\section{Research Instrument}

The data were collected through questionnaires adapted from the Total Quality Management Instrument (Zhang, Waszink \& Wijngaard, 2000), Multi-Factor Leadership (MLQ) (Avolio \& Bass, 2004) and Malaysian Teacher Standards Instrument (MOE, 2008). This study used construct validity and content validity to measure the validity of the construct and that the content can measure the true value of the concepts in this study. This study also used the items' correlational scale and internal consistency (Cronbach's Alpha) to measure their reliability.

Table 2. Items in the survey questionnaire

\begin{tabular}{|c|c|c|c|}
\hline Section & Dimension & Dimension & Total \\
\hline \multirow[t]{3}{*}{ A } & \multirow[t]{3}{*}{ Demographic Profile } & Gender & 1 \\
\hline & & Level of Education & 1 \\
\hline & & Locality of School & 1 \\
\hline \multirow[t]{6}{*}{ B } & \multirow[t]{6}{*}{ Total Quality Management } & Customer Focus & 6 \\
\hline & & Management Leadership & 8 \\
\hline & & Teachers Involvement & 8 \\
\hline & & Continuous Improvement & 9 \\
\hline & & Reward and Acknowledgement & 6 \\
\hline & & Education and Training & 6 \\
\hline \multirow[t]{4}{*}{ C } & \multirow[t]{4}{*}{ Transformational Leadership } & Ideal Influence & 7 \\
\hline & & Inspiration Motivation & 9 \\
\hline & & Intellectual Brainstorm & 8 \\
\hline & & Individual Consideration & 10 \\
\hline \multirow[t]{3}{*}{$\mathrm{D}$} & \multirow[t]{3}{*}{ Teacher Quality } & Teacher Professionalism Practice & 26 \\
\hline & & Knowledge and Understanding & 21 \\
\hline & & Teaching and Learning Skill & 24 \\
\hline
\end{tabular}

\section{Data Analysis}

The statistical analyses used include descriptive statistics, Pearson correlation coefficient 
(Pearson Product - Moment Correlation Coefficient) and mediator variable analysis (SPSS MACRO PROCESS 3.0) introduced by (Hayes, 2013). The data collected were then analysed using the SPSS (Statistical Package for the Social Sciences) software, which was designed to analyse data and information collected statistically. In addition to the descriptive statistics, the Pearson Correlation Coefficient and Mediator Variables Macro Process 3.0 were conducted to examine the relationships between the variables and to answer the research objectives through the statistical analysis of data collected. Prior to the detailed data analysis, Exploratory Data Analysis was conducted for data identification.

\section{Research Finding}

Table 3. The correlation between total quality management and transformational leadership

\begin{tabular}{|c|c|c|c|}
\hline Total Quality & Pearson Correlation & 1 & $.768^{* *}$ \\
Management & Sig. (2-tailed) & & .000 \\
& $\mathrm{~N}$ & 423 & 423 \\
\hline Transformational & Pearson Correlation & $.768^{* *}$ & 1 \\
Leadership & Sig. (2-tailed) & .000 & 423 \\
& $\mathrm{~N}$ & 423 & 423 \\
\hline
\end{tabular}

** Significant at 0.01

The results in Table 3 showed that the variables for total quality management are positively correlated with transformational leadership $(r=.768, n=423, p=.000)$. It can be concluded that total quality management has a high correlation with transformational leadership.

Table 4. Pearson Correlation test for the relationship between total quality management and transformational leadership

\begin{tabular}{|c|c|c|c|}
\hline \multirow{2}{*}{} & \multicolumn{3}{|c|}{ Transformational Leadership } \\
\cline { 2 - 4 } & Sig. Value & $\mathrm{r}$ & Interpretation \\
\hline Customer focus & .000 & .565 & High correlation \\
\hline Leadership & .000 & .618 & High correlation \\
\hline Employee participant & .000 & .497 & Moderate correlation \\
\hline Continuous improvement & .000 & .642 & High correlation \\
\hline Reward & .000 & .755 & High correlation \\
\hline Education & .000 & .635 & High correlation \\
\hline
\end{tabular}

The results in Table 4 show that variables of total quality management recorded the correlation coefficient close to 1.0. In this regard, what distinguished each factor is the Pearson correlation coefficient, as shown. Education obtained the r of .635, which is lower than $.05(p<.05)$, indicating a moderate level of correlation. In term of students' focus, the Pearson correlation coefficient is .565 , indicating a strong relationship. Similarly, administrative leadership obtained a correlation coefficient of .618, which indicates a strong high correlation. Teachers' engagement also showed a moderate correlation coefficient of .497, while continuous improvement showed a high correlation coefficient with .642. Last, rewards obtained the highest correlation coefficient 
INTERNATIONAL JOURNAL OF ACADEMIC RESEARCH IN PROGRESSIVE EDUCATION AND

DEVELOPMENT

Vol. 9, No. 2, 2020, E-ISSN: $2226-6348$ @ 2020 HRMARS

with .755.

Table 5. correlational analysis between transformational leadership and teachers' quality

\begin{tabular}{|c|c|c|c|}
\hline & & Transformational Leadership & Teachers Quality \\
\hline $\begin{array}{c}\text { Transformational } \\
\text { Leadership }\end{array}$ & $\begin{array}{c}\text { Pearson } \\
\text { Correlation } \\
\text { Sig. (2-tailed) } \\
\mathrm{N}\end{array}$ & $\begin{array}{c}1 \\
423\end{array}$ & $\begin{array}{c}.846 * * \\
.000 \\
423\end{array}$ \\
\hline Teachers Quality & $\begin{array}{c}\text { Pearson } \\
\text { Correlation } \\
\text { Sig. (2-tailed) } \\
\mathrm{N}\end{array}$ & $\begin{array}{c}.846^{* *} \\
.000 \\
423\end{array}$ & $\begin{array}{c}1 \\
423\end{array}$ \\
\hline
\end{tabular}

** Significant at sig 0.01

The results in Table 5 show that the variables for transformational leadership are significantly and positively correlated to teachers' quality (.846).

Table 6. Pearson correlation of the relationship between transformational leadership and

\begin{tabular}{|c|c|c|c|}
\hline \multicolumn{4}{|c|}{ teacher quality } \\
\cline { 2 - 4 } & Sig. Value & $\mathrm{r}$ & Teachers Quality \\
\hline Idealized Influence & .000 & .768 & High correlation \\
\hline Inspirational Motivation & .000 & .787 & High correlation \\
\hline Intellectual Stimulation & .000 & .780 & High correlation \\
\hline Individualized Consideration & .000 & .782 & High correlation \\
\hline
\end{tabular}

As shown in Table 6, all domains of transformational leadership showed a positive and significant relationship with teachers' quality. However, each domain recorded different Pearson correlation coefficients. The coefficient for 'ideal influence' is significant at .768, indicating a strong relationship. Similarly, the domain of 'inspirational motivation' showed a correlation coefficient of .787, which also indicates a strong relationship. The domain 'Intellectual stimulus' also showed a high correlation coefficient with .780 while the domain of individual judgments a high correlation coefficient at.782.

Table 7. Correlation test between TQM and teacher quality

\begin{tabular}{|c|c|c|c|}
\hline \multicolumn{2}{|c|}{} & Total Quality Management & Teacher Quality \\
\hline Total Quality & Pearson Correlation & 1 & $.942^{* *}$ \\
Management & Sig. (2-tailed) & & .000 \\
& $\mathrm{~N}$ & 423 & 423 \\
\hline Teacher & Pearson Correlation & $.942^{* *}$ & 1 \\
Quality & Sig. (2-tailed) & .000 & 423 \\
& $\mathrm{~N}$ & 423 & 4 \\
\hline
\end{tabular}

* Significant at sig. level 0.01 
INTERNATIONAL JOURNAL OF ACADEMIC RESEARCH IN PROGRESSIVE EDUCATION AND DEVELOPMENT

Vol. 9, No. 2, 2020, E-ISSN: $2226-6348$ @ 2020 HRMARS

Table 7 shows that the variables for total quality management are positively and significantly linked to teacher quality at .942 .

Table 8. Pearson Correlation of the relationship between TQM and teacher's quality

\begin{tabular}{|c|c|c|c|}
\hline \multirow{2}{*}{ Customer focus } & \multicolumn{3}{|c|}{ Teacher Quality } \\
\cline { 2 - 4 } & Sig. Value & $r$ & Interpretation \\
\hline Leadership & .000 & .766 & High correlation \\
\hline Employee participant & .000 & .815 & High correlation \\
\hline Continuous improvement & .000 & .675 & Moderate correlation \\
\hline Reward & .000 & .830 & High correlation \\
\hline Education & .000 & .636 & Moderate correlation \\
\hline & .000 & .814 & High correlation \\
\hline
\end{tabular}

Table 8 shows that all factors related to Total Quality Management practices have a positive and significant relationship with teachers' quality. However, each factor recorded different Pearson correlation coefficients. In terms of students' focus, the correlation coefficient is at .766. This indicates a strong relationship. Furthermore, administrative leadership showed a correlation coefficient of .815, which also indicates a strong relationship. Similarly, continuous improvement has a high correlation coefficient at .814, while the aspect of education and training has shown the highest correlation coefficient at .830. Two factors recorded a moderate correlation coefficient,

teachers' involvement with the correlation coefficient of .675, and rewards and recognition with a moderate correlation coefficient of .636. In all, the correlation between total quality management practices and teacher quality is high at .942 .

Table 9. SPSS Macro Process 3.0 analysis on the moderator role of transformational leadership in the relationship between TQM and teachers' quality

\begin{tabular}{|c|c|c|c|c|c|}
\hline \multirow[t]{2}{*}{ Path } & \multirow{2}{*}{$\begin{array}{l}\text { Unstandardized } \\
\text { Coefficients (B) }\end{array}$} & \multirow[t]{2}{*}{ SE } & \multirow{2}{*}{$\begin{array}{l}\mathrm{P} \text { (two- } \\
\text { tailed) }\end{array}$} & \multicolumn{2}{|c|}{ 95\% Confidence Interval (CI) } \\
\hline & & & & Lower Level & Upper Level \\
\hline $\begin{array}{c}\text { Total effect } \\
\text { (without mediator } \\
\text { path c) } \\
\text { TQM } \rightarrow \text { TQ }\end{array}$ & .7985 & .0139 & .0000 & .7712 & .8258 \\
\hline $\begin{array}{c}\text { Direct effect } \\
\text { (with mediator path } \\
c^{\prime} \text { ) } \\
\text { TQM } \rightarrow \text { TQ }\end{array}$ & .6037 & .0178 & .0000 & .5687 & .6386 \\
\hline Indirect effect & & & & & \\
\hline TQM $\rightarrow$ TL (path a) & .7396 & .0301 & .0000 & .6804 & .7987 \\
\hline $\mathrm{TL} \rightarrow \mathrm{TQ}$ (path b) & .2634 & .0185 & .0000 & .2272 & .2997 \\
\hline $\mathrm{APK} \rightarrow \mathrm{GKP} \rightarrow \mathrm{KG}(\mathrm{ab})$ & .1948 & .0006 & .0000 & .1546 & .1837 \\
\hline
\end{tabular}


Table 9 shows the results of the moderator role of transformational leadership in the relationship between total quality management and teacher quality. It was found that the $p$-value for overall quality management is $p=.000$, which is smaller than the significant value $(p<.05)$. The result shows that total quality management can influence the quality of teachers. The overall effect without intermediate path c from total quality management to teacher quality indicates a Beta value of .7985. This result means that overall quality management can influence teacher quality by 79.85 per cent. It was also observed that there is a positive influence between comprehensive quality management and intermediary variables, specifically transformational leadership, which represents a path with Beta $=.7396$ and $p$-value of .000 . These values indicate that total quality management can influence transformational leadership by 73.96 per cent. Concerning the moderator role of transformational leadership on teacher quality, the result shows that the beta value of transformational leadership on teacher quality is .2634 and $p=.000$. This result indicates that route $b$ has a significant and positive relation effect. This indicates that a one per cent change in transformational leadership will improve teacher quality by 26.34 per cent. Furthermore, there is a direct relationship between total quality management and teacher quality, with the direct effect of intermediate $c$ is .6037 . Whereas, the indirect relationship with transformational leadership is .1948 . The results of this analysis indicate that transformational leadership has a positive and significant moderator effect in the relationship between total quality management and teacher quality.

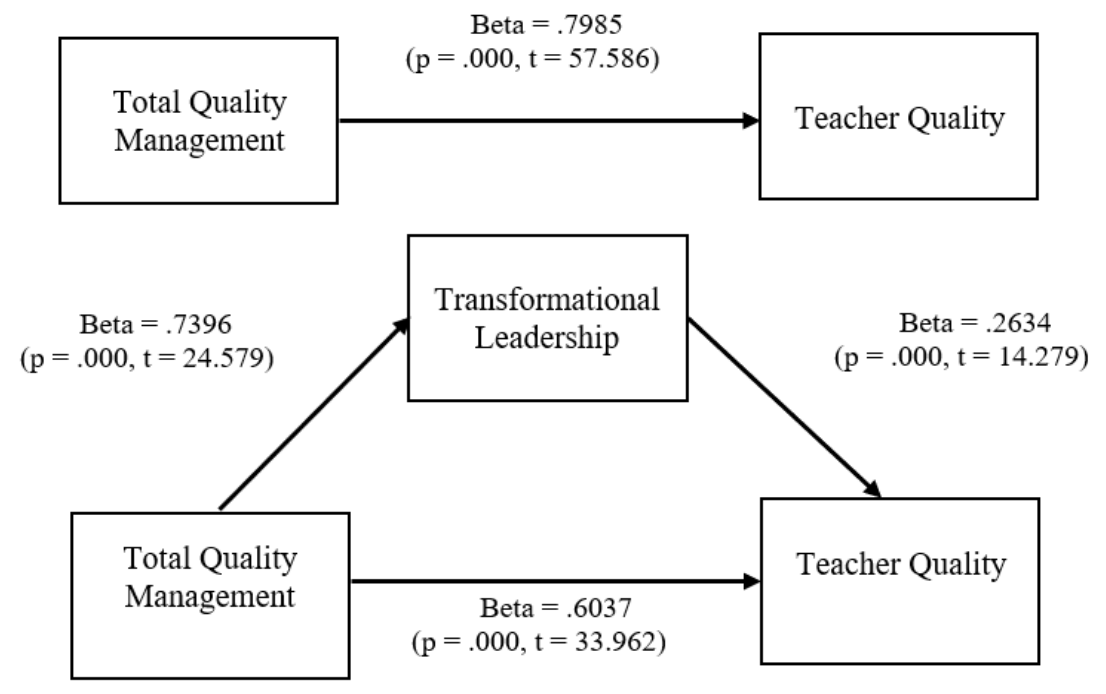

Figure 2. The mediator role of transformational leadership in the relationship between holistic quality management and teacher quality.

The mediator effect can be calculated using the Variable Accounted For (VAF) index as follows:

$=a b /\left(c^{\prime}+a b\right)$

$=.7396(.2634) /(.6037+.1948)$

$=.1948 / .7985$

$=.244$ 
The VAF for indirect effects (mediator effect) is .244. This result shows that transformational leadership style has a $24.4 \%$ effect in the relationship between total quality management and teacher quality. Thus, it can be concluded that the transformational leadership style has a partial mediator effect on the relationship between total quality management and teacher quality.

\section{Discussion}

The data analysis revealed four significant findings from this study. First, Total Quality Management has a high correlation with transformational leadership. This finding is supported by (Berson \& Linton, 2005; Kumar \& Sharma, 2017; Young \& Joo, 2014), which have proven that total quality management has a significant relationship with transformational leadership. The findings of the study also support the findings of (Ehigie \& Akpan, 2004) that reward is the total quality management factor with the highest correlation compared to other factors. This study's finding reflects that transformational leadership can be enhanced among school principals when total quality management is implemented in schools, particularly in providing rewards and recognition for teachers.

The next significant finding is that transformational leadership has a positive relationship and high correlation with teacher quality. This finding is in line with several past studies (Boberg \& Bourgeois, 2016; Eyal \& Roth, 2011; Geijsel, Sleegers, Leithwood \& Janzi, 2006; Menon, 2014; Pounder, 2014; Rao, 2014; Yu, Leithwood \& Jantzi, 2002) that demonstrated the impact of transformational leadership relationship to teachers' quality in schools. In this regard, transformational leadership can positively transform teachers' attitude and behaviour, and subsequently, improves teachers' quality through principal's charisma, motivation and inspiration, increasing intellectual engagement and making individual judgments appropriate to the situation.

The third significant finding is that Total Quality Management has a high correlation with teacher quality. This finding is supported by (Hoque, Alam \& Abdullah, 2011; Suarman, 2015; Rahman, Nabi, Akhter, Saeed \& Ajmal, 2011). These studies argued that total quality management could improve teachers' quality. In addition, the findings show that reward and recognition are the factors with the strongest relationship with teacher quality, as shown in (Dee \& Wyckoff, 2015; Kirunda, 2004). This finding shows that total quality management is a practice that can improve teachers' quality and schools' effectiveness. In this regard, each factor in the Total Quality Management practices plays an important role in shaping the quality of teachers.

The final finding indicates that transformational leadership has a mediator effect in the relationship between total quality management relationship and teachers' quality. Thus, if total quality management practices are implemented directly, the quality of teachers can still be improved, but at a lower rate. On the other hand, the quality of teachers will be enhanced when the principal implements transformational leadership. This indicates that principals need to implement transformational leadership to change teachers' attitudes and behaviours in accepting total quality management in schools, and subsequently, improves teachers' quality in schools. Hence, a high-quality school relies on the competency of the school organization work culture in managing change (Davies \& Burnham, 2010; Nor, Mansor \& Suliman, 2018). 
DEVELOPMENT

Vol. 9, No. 2, 2020, E-ISSN: 2226-6348 @ 2020 HRMARS

\section{Contribution}

Through this study, there is a perspective indicating that total quality management can be applied in the field of education especially in improving the quality of schools and teachers. The educational organizations must dare to use these total quality management as one of the guidelines in managing schools.

In addition, this study also produces a model of teacher quality based on the total quality management and principals' transformational leadership. This model can be used by Ministry of Education, schools and educational practitioners to develop the quality of teachers in future. It also further develops the quality of teachers through proper management practice and transformational leadership style. This method saves more cost in sending teachers to get selfdevelopment education and training.

Among the aspects that need to be considered in the development of teacher quality is to improve the teacher professionalism practice. This encompasses personal domain, professional domain and social domain. Pertaining personal domain aspect, this study is seen to increase teachers' trust in God, nature of trust, sincerity, knowledge, love, patience, courtesy, fair, strengthen resilience, fit, active, healthy, possess interpersonal skills and intrapersonal, has a high voluntary spirit and act efficiently. Meanwhile, the professional domain can be enhanced through nurturing love for the profession, skilful, integrity, set a good example, practise teamwork, act proactively and produce creative and innovative ideas. In addition, social domain includes harmony, social skill, social spirit, patriotism and love of environment.

In addition, this study also contributes in improving the knowledge and understanding of teachers through the items in the questionnaire. Teachers will be able to increase their knowledge and understanding of the philosophies, goals and objectives in education. In addition, teachers' knowledge and understanding of philosophy, goals, curriculum and co-curriculum objectives, learning outcomes can also be enhanced and explained in details. In fact, teachers' knowledge and understanding of subjects, educational knowledge, use of information and communication technology as well as educational resources will also be enhanced. Moreover, teachers' knowledge and understanding of strategies to create learning environment, assessment and evaluation and action research as well as the development of student potential can be enhanced through teacher quality understanding and improving.

The description of items in the questionnaire is also expected to contribute to the development of teachers' teaching and learning skills. Teachers can also improve the skills through effective approaches, methods and techniques in the classroom. Furthermore, the skills of monitoring, assessing and evaluating are further strengthened through the quality assurance mechanisms that have been discussed in this study. In fact, classroom management skills can also be improved through the implementation of rules, environment, layout and resource planning as well as effective time by the teacher.

\section{Conclusion}

The findings of this study could help increase the existing understanding and knowledge on Total Quality Management, transformational leadership and teacher quality. In conclusion, the findings suggest that Total Quality Management and transformational leadership can contribute 
to improving teachers' quality. A principal's implementation of transformational leadership gain will support teachers' development. Such support will lead to increased professionalism, knowledge and understanding, as well as higher ability to facilitate the teaching and learning process. This study has several implications for schools as the finding shows the need to find the right approach to encourage teachers to involve actively in school activities and compete with each other. In this regard, higher teachers' involvement will improve the teachers' teaching quality and subsequently, the quality of the school. Based on this implication, the Ministry of Education should strive to implement Total Quality Management to ensure the continuous improvement of teachers' quality. More courses and workshops on Total Quality Management could be conducted to educate teachers on the importance of such practices in strengthening teachers' quality in the future. Therefore, the findings of this study can contribute to improving school management practices, specifically in the implementation of total quality management, transformational leadership and teachers' quality. Furthermore, this study could become a source of information for school management to help them develop more detailed plans in implementing Total Quality Management and improve teachers' quality. The results of this study also provide useful inputs for all parties in identifying the role of Total Quality Management in the 21st-century education system.

\section{Recommendation}

Future studies could further elaborate and expand the study by involving teachers and administrators from other types of school, such as boarding schools, religious schools and high performing schools. This study can also be extended to private schools and all educational institutions to improve the quality of their management and education services.

Therefore, future studies are recommended to use longitudinal studies that collect data repeatedly from samples over a long period of time. Longitudinal studies can provide consistent and more transparent data. Furthermore, as a longer study period could lead to more reliable findings, the number of respondents can also be increased, and a wider area could be covered.

Future studies could also use structural equation modeling (SEM) or path analysis that can identify variables of total quality management practices that directly or indirectly affect to principal's transformational leadership and teacher quality. In addition, this method can also formulate a model of factors that can influence the principal's transformational leadership and teacher quality through total quality management practices.

\section{References}

Abu-Doleh, J. D. (2012). Human resource management and total quality management linkage rhetoric and reality: Evidence from an empirical study. International Journal of Commerce and Management 22(3): 219-234.

Alnawasreh, R. I., Nor, M. Y. M., \& Suliman, A. (2019). Factors Affecting Malaysian International High School Students' Performance: The Moderating Effect of Transformational Leadership. Humanities and Social Sciences Reviews, 7, 5, 1262-1271. 
INTERNATIONAL JOURNAL OF ACADEMIC RESEARCH IN PROGRESSIVE EDUCATION AND

DEVELOPMENT

Vol. 9, No. 2, 2020, E-ISSN: $2226-6348 @ 2020$ HRMARS

Alolayyan, M. N., Ali, K. A. M., \& Idris, F. (2011). The influence of total quality management (TQM) on operational flexibility in Jordanian hospitals: Medical workers' perspectives. Asian Journal on Quality 12: 204-222.

Arifin, Z., Mustapa, A. M., My, A. E., Arab, J. P., Islam, D. T., Islam, F. P., \& Ahmad, M. (2014). Kualiti Guru Bahasa Arab Dalam Konteks Malaysia: Menangani Persoalan Asas. 1-10.

Avolio, B. J., \& Bass, B. M. (2004). Multifactor leadership questionnaire, manual and sampler set (3rd ed.). Redwood City: Mind Garden.

Bass \& Bass. (2008). The Bass handbook of leadership: Theory, research, and managerial applications (4th ed.). Free Press: New York.

Bass, B. M. (1985). Leadership and performance beyond expectations. Free Press: New York.

Berson, Y., \& Linton, J. (2005). An examination of the relationships between leadership style, quality, and employee satisfaction in $R \& D$ versus administrative environments. $R$ and $D$ Management, 35, 1, 51-60, 2005.

Blanton, L. P., Sindelar, P. T., \& Correa, V. I. (2006). Models and measures of beginning teacher quality. The Journal of Special Education. Vol. 40 No. 2. pp. 115-127.

Boberg, J. E., \& Bourgeois, S. J. (2016). The effects of integrated transformational leadership on achievement. Journal of Educational Administration, Vol. 54, Issue 3, 357-374.

Burns, J. M. (1978). Leadership. New York. Harper \& Row.

Chang, C. C., Chiu, C. M., \& Chen, C. A. (2010). The effect of TQM practices on employee satisfaction and loyalty in government. Total Quality Management \& Business Excellence 21(12): 1299-1314.

Davies, B., \& Burnham, J. W. (2010). Reengineering and total quality in school. Pearson Education: United Kingdom.

Dee, T. S., \& Wyckoff, J. H. (2015). Incentives, Selection, and Teacher Performance: Evidence from Impact. Journal of Policy Analysis and Management, 34, 2, 267-297.

Ehigie, B. O., \& Akpan, R C. (2004). Roles of perceived leadership styles and rewards in the practice of total quality management. Leadership \& Organization Development Journal, Vol. 25, Issue 1, 24-40.

Eksan, S. H. R., \& Bakar, N. R. A. (2017). Amalan Pengurusan Kualiti Menyeluruh dalam Pengajaran dan Pembelajaran Melalui Kaedah QFD. Malaysian online Journal of Education. Vol, 1. No. 1. 12-19.

Eyal, O., \& Roth, G. (2011). Principals' leadership and teachers' motivation: Self-determination theory analysis. Journal of Educational Administration, Vol. 49, Issue 3, 256-275.

Geijsel F., Sleegers P., Leithwood K., \& Jantzi, D. (2006). Transformational leadership effects on teachers' commitment and effort toward school reform. Journal of Educational Administration, Vol. 41, Issue 3, 228-256, 2006.

Goe, L. (2007). The link between teacher quality and student outcomes: A research synthesis. Washington, DC: National Comprehensive Center for Teacher Quality.

Hamzah, M. I., Mat, F., Nordin, N., \& Rahman, S. (2011). School as Learning Organization: The Role of Principal's Transformational Leadership in Promoting Teacher Engagement. World Applied Sciences Journal, 14.

Hayes, A. F. (2013). Introduction to Mediation, Moderation, and Conditional Process Analysis. The Guilford Press: New York. 
Hoque, K. E., Alam, G. M., \& Abdullah, A. G. K. (2011). Impact of teachers' professional development on school improvement-an analysis at Bangladesh standpoint. Asia Pacific Education Review, 12, 3, 337-348.

Ishak, R., \& Rusman. S. N. F. (2018). Prestasi Kerja Guru dan Hubungannya dengan Faktor Beban Tugas, Persekitaran Kerja dan Personal: Kajian Kes di Sebuah Sekolah di Sabah. Jurnal Kepimpinan Pendidikan, Bil 5, Isu 1.

Jayaram, J., Ahire, S., Nicolae, M., \& Ataseven, C. (2011). The moderating influence of product orientation on coordination mechanisms in total quality management. International Journal of Quality \& Reliability Management 29(5): 531-559.

Kirunda, H. K. (2004). Performance-Based Rewards and the Performance of Teachers in Private Secondary Schools in Kampala District. Journal of Business Strategies, 7, 5, 132-145.

Koch, J. V. (2003). TQM: Why is its impact in higher education so small? TQM Magazine 15(5): 325-333.

Kumar V., \& Sharma R. R. K. (2017). Relating management problem-solving styles of leaders to TQM focus: an empirical study. The TQM Journal, Vol. 29, Issue 2, 218-239.

Lam, M. Y., Poon, G. K. K., \& Chin, K. S. (2008). An organizational learning model for vocational education in the context of TQM culture. International Journal of Quality Reliability Management 25(3): 238-255.

Leithwood, Jantzi, Dimmock, Goh, Mulford, Kendall, \& Ewington. (2012). Jossey-Bass. JosseyBass Reader on Educational Leadership (3rd Edition). Somerset, NJ, USA.

Lent, R. W., \& Brown, S. D. (2006). Integrating person and situation perspectives on work satisfaction: A social-cognitive view. Journal of Vocational Behavior, 69, 2, 236-247.

Mau, W. J., Ellsworth, R., \& Hawley, D. (2004). Job satisfaction and career persistence of beginning teachers. The International Journal of Educational Management, 22, 1, 48-61.

Menon, M. E. (2014). The relationship between transformational leadership, perceived leader effectiveness and teachers' job satisfaction. Journal of Educational Administration, Vol. 52, Issue 4, 509-528.

MOE. (2007). Pekeliling kurang tugas guru 2012, Ministry of Education, 1-22.

MOE. (2008). Malaysian Teachers Standard (SGM), Ministry of Education.

MOE. (2016). Pelan Induk Pembangunan Profesionalisme Keguruan (PIPPK). Ministry of Education Malaysia, 1-53.

Morrow, P. C., Mcelroy, J. C., \& Scheibe, K. P. (2011). Work unit incivility, job satisfaction, and total quality management among transportation employees. Transportation Research Part E: Logistics and Transportation Review 47(6): 1210-1220.

Nawelwa, J., Sichinsambwe, C., \& Mwanza, B. G. (2015). An analysis of total quality management (TQM) practices in Zambian secondary schools. The TQM Journal 27(6): 716731.

Nilsen, Trude \& Gustafsson. (2016). Teacher Quality, Instructional Quality and Student Outcomes. Springer International Publishing: New York.

Nor. M. Y. M., Mansor, A. N., \& Suliman, A. (2018). The Practice of School Based Management: Special Reference to Malaysian Clusters Schools and UK Autonomous Schools. Journal of Advance Research in Dynamical and Control Systems, 10, 2, 1618-1626.

Nordin, A. B., \& Othman, I. (2008). Falsafah Pendidikan dan Kurikulum. Quantum Books: Tanjung 
INTERNATIONAL JOURNAL OF ACADEMIC RESEARCH IN PROGRESSIVE EDUCATION AND

DEVELOPMENT

Vol. 9, No. 2, 2020, E-ISSN: $2226-6348$ @ 2020 HRMARS

Malim.

Oakland, J. (2014). Total Quality Management and Operational Excellence. Routledge: London.

Oluwatoyin, A., \& Oluseun, A. (2014). Total Quality Management: A Test of the Effect of TQM on Performance and Stakeholder Satisfaction. Journal of Clinical Nursing 5(1): 2007-2012.

Ooi, K. B., Bakar, N. A., Arumugam, V., Vellapan, L., \& Loke, A. K. Y. (2007). Does TQM influence employees' job satisfaction? An empirical case analysis. International Journal of Quality \& Reliability Management. 24(1): 62-77.

Pounder, J. (2014). Quality teaching through transformational classroom leadership. Quality Assurance in Education, Vol. 22, Issue 3, 273-285.

Psomas, E., \& Fotopoulos, C. (2010). Total quality management practices and results in food companies. International Journal of Productivity and Performance Management. 59(7): 668-687.

Rahim, A., Rahman, A., \& Daud, K. (2012). Hubungan antara sistem pengurusan sekolah kualiti (SPSK) dengan kualiti dan produktiviti guru di sekolah rendah daerah Johor Bahru. Masters Dissertation, Universiti Teknologi Malaysia.

Rahman, F., Nabi, J., Akhter, Y., Saeed, C., \& Ajmal, M. (2011). Relationship Between Training Of Teachers And Effectiveness Teaching. International Journal of Business and Social Science, 2, 150-160.

Rao, M. S. (2014). Transformational leadership - an academic case study. Industrial and Commercial Training, Vol. 46, Issue 3, 150-154.

Sakthivel, P. B., Rajendran, G., \& Raju, R. (2005). TQM implementation and students' satisfaction of academic performance. The TQM Magazine. 17. 573-589.

Sallis, E. (2008). Total Quality Management in Education. Zanco Journal , the Scientific Journal of Salahaddin University (36): 177.

Sanders, W., \& Rivers, J. (1996). Cumulative and Residual Effects of Teachers on Future Student Academic Achievement. Tennessee Value-Added Assessment System. University of Tennessee Value-Added Research and Assessment Centre.

Shahril, M. (2005). Amalan pengajaran guru yang berkesan: Kajian di beberapa sekolah menengah di Malaysia. Jurnal Fakulti Pendidikan Universiti Malaya, 1-14.

Sihotang, R. B., \& Zebedeus, Z. V. (2013). Relationships between Total Quality Management Practices, Organizational Culture and Teacher's Performance: Study from Seventh Day

Adventist High Schools in West Indonesia. International Research Journal of Business Studies. 6(2): 105-119.

Singh, R. K. (2011). Analyzing the interaction of factors for success of total quality management in SMEs. Asian Journal on Quality. 12(1): 6-19.

Suarman, S. (2015). Teaching Quality and Students Satisfaction: The Intermediatory Role of Relationship between Lecturers and Students of the Higher Learning Institutes. Mediterranean Journal of Social Sciences, 6, 2, 626-632.

Svensson, M., \& Klefsjö, B. (2006). TQM-based self-assessment in the education sector: Experiences from a Swedish upper secondary school project. Quality Assurance in Education. 14. 299-323.

Talib, F. A., Mansor, A. N., \& Surat, S. (2019). Relationship Between Headmaster Transformational Leadership Practice and Teachers' Job Satisfaction in Kuala Langat. International Journal of 
Education, Psychology and Counselling, 4, 27, 63-75.

Ugboro, I. O., \& Obeng, K. (2000). Top management leadership, employee empowerment, job satisfaction, and customer satisfaction in TQM organizations: an empirical study. Journal of Quality Management. 5(2): 247-272.

Wahab, J., Fuad, C., Ismail, H., \& Majid, S. (2014). Headmasters' Transformational Leadership and Their Relationship with Teachers' job Satisfaction and Teachers' Commitments. International Education Studies, 7, 40-48.

Yahya, Azizah \& Yaakob. (2014). Pembentukan dan peningkatan kualiti guru di Malaysia: Siri Monograf Pendidikan. Universiti Utara Malaysia Press: Sintok.

Young, S. C., \& Joo, Y. J. (2014). The verification of effective leadership style for TQM: A comparative study between USA-based firms and China-based firms. International Journal of Quality \& Reliability Management, Vol. 31, Issue 7, 822-840.

Yu, H., Leithwood, K., \& Jantzi, D. (2002). The effects of transformational leadership on teachers' commitment to change in Hong Kong. Journal of Educational Administration, Vol. 40, No. 4, 368-389.

Zhang, Z., Waszink, A., \& Wijngaard, J. (2000). An instrument for measuring TQM implementation for Chinese manufacturing companies. International Journal of Quality \& Reliability Management, Vol. 17, No. 7, 730-755. 